$\begin{aligned} & \text { Action stations } \\ & \text { Panel calls for yet } \\ & \text { another space-station } \\ & \text { overhaul } \\ & p 136\end{aligned}$
$\begin{aligned} & \text { playing catch-up } \\ & \text { George W. Bush's } \\ & \text { science adviser tries } \\ & \text { to get up to speed } \\ & p 137\end{aligned}$

\title{
Geneticists' work in disarray as DNA-chip producer pulls the plug
}

Jonathan Knight, San Francisco

A leading manufacturer of DNA chips has unexpectedly decided to get out of the business, leaving researchers scrambling to find substitutes for the company's products.

California-based Incyte Genomics announced on 24 October that it would stop making DNA chips, commonly known as microarrays, and end its gene-expression analysis service. It said the operation was no longer profitable.

It is thought that Incyte - one of the leaders in the emerging technology — is leaving the business in part because so many research institutions now make their own arrays. Incyte, which holds several key microarray patents, also authorized several companies to sell the chips and associated services.

The popularity of microarrays is currently soaring. They allow researchers to monitor the expression of many genes during process-

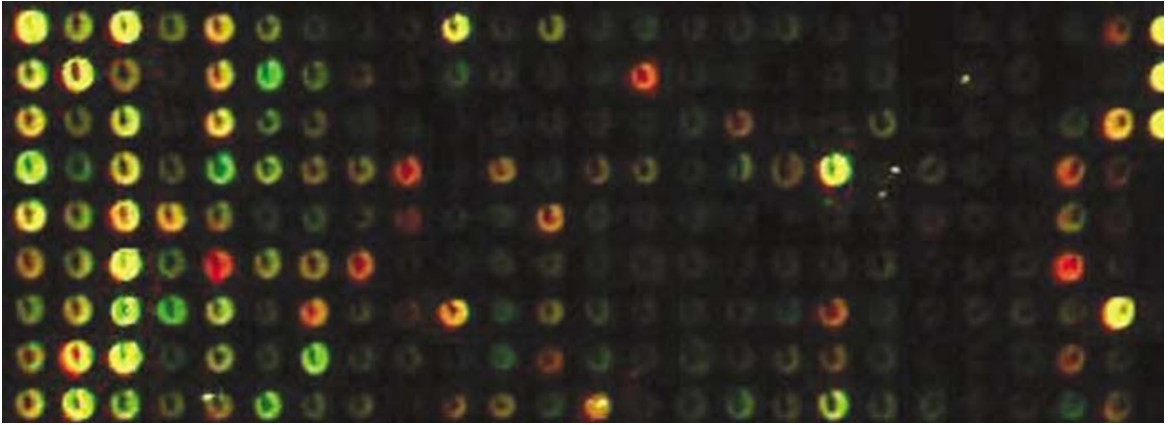

Chips for the chop: despite their popularity, microarrays are found to be unprofitable by Incyte.

es such as cancer development. An array consists of thousands of DNA spots, each corresponding to a gene. When RNA from tissue is processed and applied to the array, the spots corresponding to active genes light up.

Some Incyte users only learned of the company's decision from reporters. Among

\section{New Zealand says yes to GM trials}

Peter Pockley, Sydney

New Zealand will go ahead with field trials of genetically modified (GM) crops, but will delay their commercial release until 2003 at the earliest, the government has announced.

The decision, which follows an intense national debate, is regarded as a victory by supporters of GM technology.

Prime Minister Helen Clark said on 30 October that the government would accept most of the recommendations of the Royal Commission on Genetic Modification, which this year completed an extensive investigation of the technology (see Nature 412, 569; 2001). She said that GM technology would have a "key role" in New Zealand's agriculture and in emerging industries.

Opponents of GM technology had campaigned vigorously, attracting as many as 20,000 people to demonstrations. The government also came under pressure from its own six Maori members of parliament and from the seven environmentalists who hold the balance of power.
The government says it will allow the rights and spiritual beliefs of the indigenous Maori, who comprise $15 \%$ of New Zealand's four-million population, to be represented in the approvals process for GM research.

Mita Ririnui, chair of the Labour Maori Caucus, is pleased about the inclusion of the Maori in the process. But he warns that they will oppose the use of transgenic technology. "To interfere with another life-form is disrespectful and another form of cultural arrogance," he claims.

Research minister Pete Hodgson says the debate over GM crops has "changed New Zealand", explaining that "Pakeha [nonMaori] and Maori started to understand different world views and scientists learned they cannot exercise vetoes over others".

The government says that field trials of GM crops can begin once they have been approved under strict new rules. But there will be a two-year hold on the commercial release of genetically engineered products, with the exception of vaccines and drugs. them was Al George, director of genetic medicine at Vanderbilt University Medical School in Nashville, Tennessee, whose lab recently enlisted Incyte to develop a complementaryDNA library. He was surprised because Incyte had invested so much in creating collections of mouse and human genes, known as expressed sequence tags (ESTs), which can be deposited on glass slides to make microarrays. "They probably have one of the largest collections of ESTs on the planet," he says.

Julia Ljubimova, a cancer researcher at Cedars Sinai Medical Center in Los Angeles, says she was in the middle of a project using Incyte microarrays when the announcement came. "My project was destroyed," she says. Bruce Aronow, director of genome bioinformatics at the Children's Hospital Medical Center of Cincinnati, is also surprised by the news, and he notes that Incyte's microarrays were among the most reliable on the market.

But maintaining and replicating large collections of genes involves time-consuming quality control (see Nature 410, 860-861; 2001), and the expense may have led to shrinking profits for Incyte.

This would have been compounded by the proliferation of microarray facilities on almost every major research campus over the past two years. These typically operate with university funds or grants from the National Institutes of Health, cutting costs for academic labs doing microarray research.

James Sikela, a geneticist at the University of Colorado Health Sciences Center in Denver, says his lab used mouse arrays from Incyte for a series of experiments three years 
ago, but could not afford to use them routinely. Now, because of a new microarray facility on campus, funded in part by the National Institute on Alcohol Abuse and Alcoholism, he is getting back into microarray work. "Cost is the driving force," he says.

Incyte seems to have concluded that there is little money to be made from DNA chips. In a statement, Roy Whitfield, its chief executive officer, pointed to "increasing competition and margin erosion". As a result of the decision, some 400 workers at the company's facilities in Fremont, California, and St Louis, Missouri, will lose their jobs.

Steven Gullans, who heads the microarray centre at the Brigham and Women's Hospital in Boston, says: "Microarrays are becoming more of a commodity. The only way to compete is on price." Alternatives are available for researchers in the middle of projects with Incyte. Microarrays made using Incyte's gene collections will still be available through third-party providers such as Motorola, Agilent and PerkinElmer, the company says.

But this has led to uncertainty over compatibility, as different companies use different printing technologies. Agilent, for example, uses an inkjet printing method rather than direct DNA spotting. Several appeals for advice on alternatives have appeared on a microarray listserv at the University of California, San Francisco.

Incyte users will not be left in the lurch, says Gullans. "For the typical user in the street looking to get their sample analysed, they can find somewhere to do it," he says.

\section{Critical report leaves NASA's station strategy up in the air}

\section{William Triplett, Washington}

NASA should completely reform its management of the International Space Station (ISS), continue with its current, curtailed plan for the project, and come back in two years time for permission to restore some of the project's previous scope.

That is the recommendation of the ISS Management and Cost Evaluation Task Force, a blue-ribbon panel established by the space agency and the White House Office of Management and Budget to assess NASA's largest and most problematic programme.

If the station's crew is ever to rise to six or seven - the curtailed plan allows for only three - NASA must first prove it has the "credibility" to manage the expansion properly, says the task force. But the smaller version of the station "will not achieve the unique research potential of the ISS", the task force says, because three crew will have practically no time to run experiments.

The wait-and-see approach is the best of three options open to NASA, says the task force, which was chaired by Thomas Young, former president of defence contractor Martin Marietta, now part of Lockheed Martin.

One of the others is to build only the scaled-down version, with no possibility of returning to the original design. But this would have "a significant adverse impact on

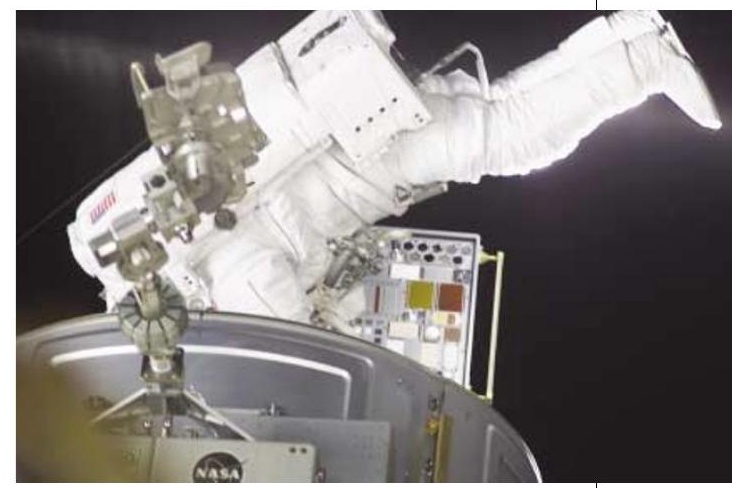

Brought to book: NASA will need to curtail its ambitions for the International Space Station.

science", says Young. The third option, of building to the original design, is simply "not credible" within the agency's likely future budget, the task force found. The ISS has already cost US $\$ 25$ billion, plus billions of dollars in launch costs.

Even the first option may not be fiscally viable: it will cost $\$ 500$ million more over the next five years than the $\$ 8.5$ billion cap that Congress has placed on the project.

The task-force report contains a dozen recommendations on how to fix the project and control its costs, including the consolidation of all ISS-related staff and activities at NASA centres across the country under a single programme office.

\section{Universities address mail security as anthrax fears rise}

Jonathan Knight, San Francisco

Worries about the mail being used for anthrax attacks have disrupted the normally benign security environments at university campuses across the United States.

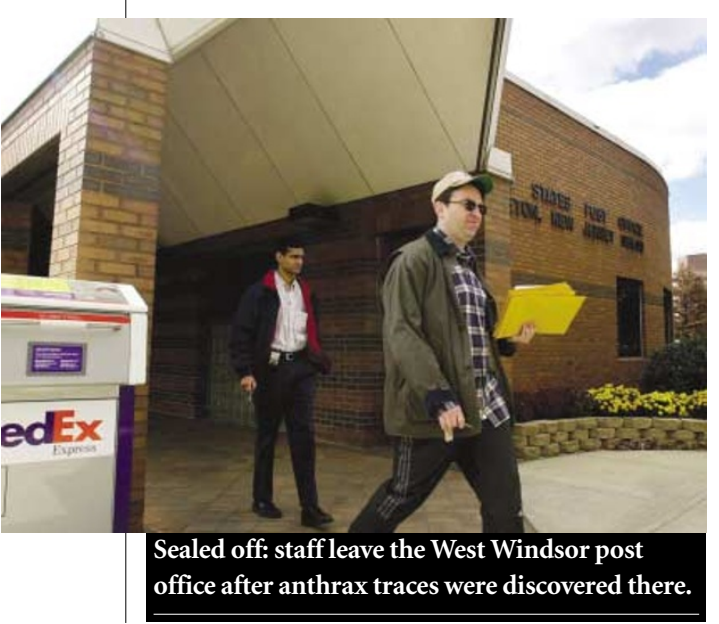

Mail deliveries to Princeton University in New Jersey were suspended for two days from 27 October after anthrax spores were found in a mail-bin at the US post office in nearby West Windsor, which serves the campus. The building remains closed, but the post office began sorting mail in its parking lot.

An administrative building at Stanford University in California, meanwhile, was evacuated and closed twice, once on 22 October and again on 30 October, while suspect letters were tested. In each case, an employee reported finding a "suspicious substance", according to the university's own news service, accompanied by a threatening letter. Both samples tested safe and in each incident the building reopened the next day.

Security is becoming a top priority on most university campuses, as reports of suspicious envelopes and packages have become commonplace. For example, Ron Ozio, a spokesman for the University of
Pennsylvania in Philadelphia, estimates that 40 or 50 envelopes received there have already been tested for anthrax and other biological hazards, although none has come back positive.

Most university websites now include advice on how to deal with suspect mail, and Princeton is requiring mail handlers to take a special training course.

Some campuses have felt the impact of the anthrax attacks in the form of subpoenas or FBI visits. A spokesman for Louisiana State University in Baton Rouge confirmed that the FBI had asked anthrax researcher Martin Hugh-Jones to provide a list of all visitors to his laboratory since January 2000.

And officials at the Brookhaven National Laboratory in New York State received a subpoena asking them to testify in the US District Court in Miami regarding the lab's anthrax work, which has consisted of studies of a protein produced by the anthrax bacterium. 